\title{
Penerapan Metode Team Teaching Untuk Meningkatkan Hasil Belajar Siswa Dalam Mata Pelajaran PAI Kelas IX Di SMP Taman Siswa Teluk Betung Bandar Lampung
}

\author{
Maskur Ahmad \\ SMPN 35 Bandar Lampung \\ maskurahmad83@gmail.com
}

\begin{abstract}
The main necessity in one's life is education. Education is a very important factor in human life. Team teaching is basically a learning method carried out by two or more teachers who collaborate in teaching groups of students which are carried out jointly by several teachers. The team or teachers who present the lesson material with the team teaching method presents the same lesson material in the same time and purpose. The type of this research is the classroom action research. The subjects were class IX A students at Taman SiswaTelukBetung Middle School in Bandar Lampung, with a total of 35 students. The data collection techniques in this research used observation, learning outcomes tests, and documentation. This research consisted of two cycles with two meetings in each cycle. The data analysis techniques were using qualitative descriptive analysis. The research success criteria set for student learning outcomes are $\geq 80$ reaching $80 \%$ based on KKM in schools. The results showed that the application of team teaching learning methods could improve the learning outcomes of class IX A students at Taman SiswaTelukBetung Middle School, Bandar Lampung. The number of students who have completed their study in the first cycle is 18 people or equivalent to $51 \%$. In the second cycle, the number of students who completed study was 31 students or equivalent to $88 \%$.
\end{abstract}

Keywords: Education, team teaching, learning outcomes.

\begin{abstract}
ABSTRAK
Kebutuhan utama dalam kehidupan seseorang ialah pendidikan. Pendidikan merupakan faktor yang sangat penting dalam kehidupan manusia. Team teaching pada dasarnya adalah metode pembelajaran yang dilakukan oleh dua orang guru atau lebih yang saling bekerjasama mengajar kelompok siswa yang dilaksanakan secara bersama oleh beberapa guru. Tim atau guru yang menyajikan bahan pelajaran dengan metode mengajar beregu ini menyajikan bahan pelajaran yang sama dalam waktu dan tujuan yang sama pula.Jenis penelitian ini merupakan jenis penelitian tindakan kelas. Subjek penelitian adalah siswa kelas IX A SMP Taman Siswa Teluk Betung Bandar Lampung, dengan jumlah 35 siswa. Teknik pengumpulan data pada penelitian ini menggunakan observasi, tes hasil belajar, dan dokumentasi. Penelitian ini terdiri dari dua siklus dengan dua kali pertemuan pada tiap siklus. Teknik analisis data menggunakan analisis deskriptif kualitatif. Kriteria keberhasilan penelitian yang ditetapkan untuk hasil belajar siswa adalah $\geq 80$ mencapai $80 \%$. berdasarkan KKM di sekolah.Hasil penelitian menunjukkan bahwa penerapan metode pembelajaran team teaching dapat meningkatkan hasil belajar siswa kelas IX A di SMP Taman Siswa Teluk Betung Bandar Lampung. Jumlah siswa yang tuntas belajar di siklus I sebanyak 18 orang atau setara dengan $51 \%$. Pada siklus II jumlah siswa yang tuntas belajar sebanyak 31 siswa atau setara dengan $88 \%$.
\end{abstract}

Kata Kunci : Pendidikan, team teaching, hasil belajar. 


\section{PENDAHULUAN}

Kebutuhan utama dalam kehidupan seseorang ialah pendidikan. Pendidikan merupakan faktor yang sangat penting dalam kehidupan manusia. Oleh karena itu dunia pendidikan dituntut untuk meningkatkan mutu dan kualitas pendidikannya. Secara khusus, sebagai seorang pendidik hendaknya berperan sebagai pengajar, pembimbing, perantara sekolah dengan masyarakat, administator, fasilitator dan lain-lain. Islam juga telah mengajarkan kita betapa pentingnya pendidikan, dimana pendidikan tersebut harus dilalui dengan berbagai proses. Jika diperhatikan siswa saat ini lebih sering mendengarkan penjelasan yang disampaikan oleh guru, jarang sekali siswa terlihat aktif bertanya dan mengemukakan pendapat. Kurangnya partisipasi dan keaktifan menyebabkan kurangnya pemahaman siswa terhadap materi yang disampaikan oleh guru yang berpengaruh pada hasil belajar yang diraih siswa.

Selain itu, selama proses pembelajaran ada beberapa siswa yang terlihat sibuk sendiri, seperti mengobrol dengan teman sebangkunya, ribut, keluar kelas dengan berbagai alasan, dan bermain handphone selama kegiatan belajar mengajar. Melihat realita yang ada antara jumlah guru dan siswa yang tidak seimbang, tentu seorang guru tidak mungkin bisa menangani jumlah siswa yang banyak. Metode pembelajaran team teaching bisa dijadikan sebagai alternatif untuk mengatasi permasalahan yang ada. Prinsip team teaching adalah ketika kegiatan belajar-mengajar berlangsung di sebuah kelas, di sana ada lebih dari satu guru. Engkoswara (2003:64) Melalui team teaching, antar guru dapat bekerja sama dan saling melengkapi dalam mengelola proses pembelajaran. Setiap permasalahan yang muncul dalam proses pembelajaran dapat diatasi secara bersama-sama. Hal serupa juga dikemukakan oleh Martiningsih (2007) Dengan metode pembelajaran team teaching diharapkan dapat memacu keaktifan siswa dalam proses belajar mengajar dan meningkatkan prestasi belajarnya.

Metode team teaching ini sangat mudah di terapkan di kelas, metode team teaching memiliki beberapa kelebihan dibanding dengan metode yang lain. Diantaranya: 1) team teaching dapat membangun budaya kemitraan dan kerjasama diantara guru. 2) team teaching dapat lebihmematangkan kegiatan perencanaan dan persiapan mengajar. 3) teamteaching dapat menjamin pengawasan pembelajaran secara efektif. 4) teamteaching dapat menjalin komunikasi yang intensif antar guru. 5) teamteaching dapat menjadi alternatif untuk memenuhi beban mengajar 24 jamdalam satu minggu. Rumusan masalah 
penelitian ini adalah "Apakah Penerapan Metode Team teaching dapat Meningkatkan hasil belajar siswa dalam mata pelajaran PAI kelas IX A ?”. Berdasarkan rumusan masalah tersebut, maka tujuan dari penelitian ini adalah untuk mengetahui peningkatan hasil belajar PAI dengan metodepembelajaran team teaching pada siswa kelas IX Adi SMP Taman Siswa.

\section{METODE PENELITIAN}

Penelitian yang dilakukan penulis adalah penelitian tindakan kelas (classroom research). Penelitian tindakan kelas merupakan sebuah upaya yang ditujukan unruk memperbaiki proses pembelajaran atau memcahkan masalah yang dihadapi dalam pembelajaran (E. Mulyasa 2009:34).

Lokasi penelitian ini dilakukan di kelas IX A SMP Taman Siswa yang terletak di Jalan W.R. Supratman No.74 Telukbetung Bandar Lampung.Waktu penelitian dilakukan pada saat pemberian tindakan menggunakan metode pembelajaran team teaching. Waktu pelaksanaan penelitian ini dilakukan pada semester 2 tahun pelajaran 2017/2018 disesuaikan dengan jadwal pembelajaran PAI kelas IX A. Pengambilan data dilakukan selama 1 bulan yaitu bulan Maret 2018, mulai tanggal 1 Maret - 26 April 2018 sebanyak 4 kali pertemuan dengan menggunakan siklus I dan siklus II. Subjek penelitian ini adalah siswa kelas IX A tahun ajaran 2017/2018 di SMP Taman Siswa Teluk Betung Bandar Lampung dengan jumlah siswa 35 orang.

Teknik pengumpulan data dilakukan dengan beberapa tahapan, diantaranya:

\section{Tes}

Tes adalah alat atau prosedur yang dipergunakan dalam rangka pengukuran dan penelitian. Dalam penelitian ini metode tes digunakan untuk menilai sampai dimana hasil belajar siswa setalah materi diajarkan.

\section{Observasi}

Observasi dilakukan peneliti dengan mengamati sekaligus menjadi bagian dan ambil bagian pada situasi yang diamati. Dengan berpedoman pada lembar observasi, peneliti mengamati apa yang terjadi dalam proses pembelajaran, yakni pelaksanaan pembelajaran dan keaktifan belajar siswa di kelas. Observasi dilakukan secara efektif dan terarah, peneliti menggunakan format observasi, dengan tujuan agar dapat melihat, mengamati, dan mencatat prilaku serta kejadian yang terjadi pada saat pembelajaran yang berlangsung dengan menerapkan metode pembelajaran team teaching. Instrumen yang digunakan 
dalam penerapan metode pembelajaran team teaching ini bertujuan untuk mengamati dan mencatat semua kegiatan yang sedang berlangsung selama proses belajar mengajar. Halhal yang diamati adalah yang sesuai dengan tujuan penelitian. Menurut J.P. Spradley (dalam Djam'an Satori \& Aan Komariah 2013:111) terdapat tiga komponen yang dapat diamati yaitu ruang (tempat), pelaku (aktor), dan kegiatan (aktivitas).

\section{Dokumentasi}

Dokumentasi merupakan data pendukung yang dikumpulkan sebagai penguat data observasi. Bentuk-bentuk dokumentasi yang dikumpulkan berupa dokumen nilai siswa dari hasil tes formatif yang diberikan, maupun hasil kegiatan praktik siswa, serta dokumendokumen lain yang dibutuhkan.

Proses pengumpulan data yang dilakukan penulis yakni dengan menginventarisasi sumber-sumber yang memang ada kaitan atau hubungannya dengan penelitian yang dilakukan. Adapun sumber-sumber yang dimaksud dapat diklasifikasikan dan dibedakan menjadi dua yakni data primer dan dan data sekunder. Data primer adalah data yang diperoleh dari subjek peneliti dengan menggunkan alat pengukuran atau pengambilan data langsung pada subjek sebagai sumber informasi yang dicari. Adapun sumber-sumber primer yang penulis maksud disini yakni sumber-sumber yang digunakan sebagai sumber utama dalam melakukan penelitian adalah buku-buku dan dokumen. Data sekunder adalah data yang diperoleh dari pihak lain tidak langsung diperoleh oleh peneliti dari subjek penelitian (Saifuddin Azwar 2010:91). Adapun sumber sekunder tersebut adalah bukubuku yang relevan, majalah atau koran.

Sementara itu analisis data ini dihitung dengan menggunakan rumus statistik sederhana. Berikut ini rumus sederhana untuk menghitung nilai rata-rata dan rata-rata persentase:

1. Menghitung nilai rata-rata

$$
X=\frac{\sum x}{n}
$$

2. Menghitung persentase

$$
P=\frac{\sum x}{n} \times 100 \%
$$

Keretangan :

$$
\begin{array}{ll}
\mathrm{X} & =\text { Rata-rata nilai } \\
\sum x & =\text { Jumlah semua nilai data } \\
\mathrm{n} & =\text { Jumlah data }
\end{array}
$$




$$
\mathrm{P} \quad=\text { Persentase }
$$

Indikator keberhasilan dalam penelitian ini adalah adanya peningkatan hasil belajar siswa dalam pembelajaran Pendidikan Agama Islam dari siklus ke siklus, yaitu dengan adanya peningkatan hasil belajar siswa yang ditandai dengan tercapainya Kriteria Ketuntasan Minimal (KKM) mata pelajaran PAI dengan nilai $\geq 80$ mencapai $80 \%$.

\section{HASIL DAN PEMBAHASAN}

\section{Pelaksanaan Siklus I}

a. Perencanaan Tindakan Siklus I

1) Peneliti menentukan materi pelajaran PAI yaitu Sejarah Tradisi Islam Nusantara sesuai dengan buku guru kurikulum 2013 dan materi tersebut pada semester genap.

2) Peneliti menyiapkan bahan ajar materi Sejarah Tradisi Islam Nusantara.

3) Peneliti membuat RPP dengan menggunakan Metode Team Teaching.

4) Peneliti membuat instrumen berupa tes objektif yaitu Postes.

5) Peneliti membuat lembar observasi.

b. Pelaksanaan Tindakan Siklus I

Setelah disiapkan rencana pembelajaran dan teknik yang akan dipakai maka proses pembelajaran akan dilaksanakan sesuai dengan rencana pembelajaran dan menggunakan strategi yang telah ditetapkan.

Hasil pengamatan pada siklus I, kegiatan siswa cukup baik dengan cukup antusias dan merespon positif kegiatan belajar mengajar. Siswa belajar cukup baik dibandingkan pada saat pra siklus. Hasrat keingintahuan siswa terhadap materi yang diajarkan siswa cukup aktif dalam pembelajaran dan sering mengajukan pertanyaan tentang materi yang belum dimengerti. Pada saat kegiatan belajar mengajar berlangsung siswa tampak antusias dengan pengalaman baru mereka, dengan 2 guru siswa lebih memahami materi kalupun siswa belum paham guru satunya akan membantu serta mengarahkan siswa yang belum paham tersebut. Meskipun ada beberapa siswa yang belum terbiasa dengan pembelajaran yang diterapkan oleh peneliti.

Berdasarkan hasil observasi (pengamatan) peneliti, hal ini dikarenakan faktor siswa yang disebabkan :

1) Masih adanya siswa yang tidak memperhatikan apa yang dijelaskan oleh guru. 
2) Masih adanya siswa yang pasif, kurangnya konsentrasi siswa disaat menerapkan metode Team Teaching, siswa masih malu untuk bertanya dan ragu-ragu menyampaikan jawaban dan pendapatnya.

3) Masih adanya siswa yang ngobrol atau asik berbicara sendiri dengan temannya.

4) Siswa mulai terlihat aktif, antusias dalam belajar dengan menggunakan metode Team Teaching.

\section{Refleksi Siklus I}

Refleksi dilakukan untuk melihat apakah masih terdapat kekurangan dalam pelaksanaan siklus I. Dalam hal ini kekurangan akan diperbaiki dalam siklus II. Kegiatan yang dilaksanakan pada tahap ini adalah :

1) Mengumpulkan semua hasil penilaian dari kegiatan pembelajaran yang telah dilaksanakan.

2) Menganalisis hasil penilaian untuk mengetahui kekurangan pembelajaran pada siklus I.

3) Merefleksikan hasil penilaian dan observasi antara peneliti, observer serta guru untuk merumuskan tindakan perbaikan pada siklus berikutnya.

Penggunaan penerapan metode Team Teaching untuk meningkatkan hasil belajar siswa pada siklus I berjalan dengan cukup baik dan diperoleh gambaran bahwa secara umum pelaksanaan pembelajaran pada siklus I ini telah terlaksana cukup baik, meskipun masih ada siswa yang pasif karena siswa belum terbiasa mengunakan metode Team Teaching.

Berdasarkan hasil tes yang telah dilakukan jumlah siswa tidak tuntas dari yang sebelumnya berjumlah 27 siswa turun menjadi 17 siswa. Dan untuk yang tuntas mengalami kenaikan dari yang sebelumnya 8 siswa di siklus I ini naik menjadi 18 siswa atau 51\% yang hasil tes nya sama atau lebih dari KKM.

\section{Pelaksanaan Siklus II}

a. Perencanaan tindakan siklus II

Pada rencana tindakan siklus II guru tetap menerapkan Metode Team Teachingpada mata Pelajaran Pendidikan Agama Islam, dengan strategi pembelajaran ini diharapkan dapat lebih membantu untuk meningkatkan hasil belajar siswa.

Untuk memperbaiki dan mempertahankan keberhasilan yang telah dicapai pada siklus I, maka dalam siklus ke II dapat dibuat perencanaan sebagai berikut :

1) Mempertahankan antusias siswa saat belajar menggunakan Metode Team Teaching. 
2) Lebih memperjelas langkah-langkah Metode Team Teaching agar peserta didik lebih memahami dan dapat lebih berkonsentrasi dengan penjelasan yang telah diberikan.

3) Memberikan motivasi kepada peserta didik bahwa mereka dapat lebih aktif dan dapat mengerjakan tugas kelompok dengan baik.

Pada perencanaan siklus II peneliti menyiapkan hal-hal agar siklus II lebih baik dari siklus I yaitu :

1) Peneliti merenungkan kekurangan-kekurangan yang terjadi pada siklus I, untuk tidak diulangi lagi pada siklus II.

2) Memotivasi peserta didik dan lebih menjelaskan langkah-langkah Metode Team Teaching.

3) Menyiapkan Rencana Pelaksanaan Pembelajaran (RPP) yang telah disusun secara bersama-sama. Hal ini agar guru dapat memahami isi dari RPP tersebut mulai dari kompetensi inti, kompetensi dasar, dan indikator.

4) Menyiapkan alat dokumentasi dan alat tulis untuk observasi.

5) Mempersiapkan jobsheet dan soal post test.

b. Pelaksanaan tindakan siklus II

Pelaksanaan siklus II dilaksanakan pada tanggal 15 Maret 2018. Pada siklus II diadakan dua (2) kali pertemuan, adapun pembelajaran dalam waktu $3 \times 45$ menit dengan kegiatan sebagai berikut.

c. Pengamatan Tindakan Siklus II

Hasil pengamatan pada siklus II menunjukkan bahwa siswa mengalami peningkatan hasil belajar yang sangat baik, siswa sangat antusias dan merespon positif kegiatan belajar mengajar. Pada tahap pendahuluan, kegiatan peserta didik cukup bagus hal ini dapat dilihat dari :

1) Sebelum membahas materi selanjutnya guru melakukan tanya jawab dan siswa sudah siap menjawab pertanyaan dari guru dan berani mengajukan pertanyaan dan pendapat.

2) Memasuki kegiatan inti, ketika guru melaksanakan metode Team Teachingsiswa sangat antusias, tidak takut untuk bertanya tentang materi yang belum dimengerti. Pada saat penjelasan materi siswa mengikuti proses pembelajaran dengan sangat baik, siswa memperhatikan apa yang sedang dijelaskan oleh guru.

3) Siswa cukup antusias dengan pengalaman baru mereka.

d. Refleksi Siklus II 
Pelaksanaan pembelajaran siklus ini tetap sama yaitu bertujuan meningkatkan hasil belajar siswa terhadap mata pelajaran Pendidikan Agama Islam. Pada siklus II ini, siswa sudah mengerti dan paham dengan metode pembelajaran yamg telah diterapkan peneliti, bahkan mayoritas dari mereka sudah terbiasa dengan metode pembelajaran yang peneliti terapkan di kelas IX A SMP Taman Siswa Teluk Betung.

Dari hasil pengamatan peneliti di kelas IX A SMP Taman Siswa Teluk Betung ternyata tindakan yang lakukan oleh peneliti sesuai dengan harapan yang diinginkan. Penggunaan metode Team Teachinguntuk meningkatkan hasil belajar siswa pada siklus II berjalan dengan baik. Hal ini terlihat pada antusias siswa mengikuti pelajaran dan hasil belajar siswa dalam memperhatikan guru di depan. Hal ini dapat dilihat dari :

1) Kegiatan belajar mengajar dengan metode Team Teachingdapat meningkatkan hasil belajar siswa dalam mengikuti pembelajaran di kelas dengan ditunjukkan meningkatnya hasil tes mereka.

2) Siswa mampu memecahkan suatu permasalahan dengan baik.

Berdasarkan hasil tes yang telah dilakukan semua siswa tidak tuntas dari yang sebelumnya di siklus 1 berjumlah 17 siswa turun menjadi 4 siswa di siklus II. Dan yang tuntas dari yang sebelumnya di siklus 118 (51\%) siswa di siklus II ini naik menjadi 31 (88\% ) siswa yang hasil tes nya sama atau lebih dari KKM.

Peneliti tindakan kelas ini berlokasi di SMP Taman Siswa Teluk Betung dan dilaksanakan selama dua siklus. Siklus I dilaksanakan 2 kali pertemuan yaitu pada tanggal 1 Maret dan 8 Maret 2018, siklus II hanya dilaksanakan 2 kali pertemuan juga, yaitu pada tanggal 15 Maret dan 22 Maret 2018. Pada siklus pertemuan pertama materi yang dipelajari tentang Sejarah Tradisi Islam Nusantara. Siklus II membahas materi Sejarah Tradisi dan Masuknya Islam di Nusantara. Sebelum pembelajaran dilaksanakan terlebih dahulu peneliti melakukan observasi proses pembelajaran dan konsultasi bersama guru mata pelajaran Pendidikan Agama Islam mengenai proses pembelajaran dengan penerapan Metode Team Teachingyang dilakukan. Kemudian dilanjutkan dengan menyiapkan perangkat pembelajaran seperti: silabus, RPP, lembar observasi, catatan lapangan dan lembar kegiatan peserta didik. Dari catatan lapangan dan data hasil belajar maka dapat dilihat sebagai berikut :

\section{Analisis tindakan pembelajaran pada siklus I}

a) Proses belajar mengajar 
Pada siklus I dilaksanakan sebanyak dua kali pertemuan yaitu pada tanggal 1 dan 8Maret 2018, dimana alokasi waktu setiap pertemuan 3x45 menit, setiap pertemuan dihadiri 35 peserta didik yang terdiri dari 19 siswa laki-laki dan 16 siswa perempuan. Sebelum pembelajaran di kelas dilakukan, peneliti telah menyiapkan perangkat pembelajaran seperti silabus, RPP yang terdiri dari kegiatan pendahuluan, kegiatan inti dan kegiatan penutup atau refleksi menyiapkan bahan pelajaran yang akan digunakan dalam kegiatan belajar mengajar.

Dalam pelaksanaan siklus I, materi yang dibahas adalah Sejarah Tradisi Islam Nusantara dan menerapkan Metode Team Teachingdalam proses belajar mengajar dengan tujuan untuk meningkatkan hasil belajar siswa terhadap materi Pendidikan Agama Islam b) Analisis hasil belajar peserta didik pada siklus I

Tes yang dilakukan pada siklus I ini mencakup materi Sejarah Tradisi Islam Nusantara, sebanyak 10 soal essay. Secara keseluruhan pembelajaran pada tindakan siklus I ini belum begitu baik.

\section{Analisis pembelajaran pada siklus II}

a) Proses belajar mengajar

Pada siklus II dilaksanakan dua kali pertemuan yaitu pada hari kamis tanggal 15dan 22 Maret 2018, dimana alokasi waktu setiap pertemuan 3x45 menit, setiap pertemuan dihadiri 35 peserta didik yang terdiri dari 19 siswa laki-laki dan 16 siswa perempuan. Sebelum memasuki siklus II peneliti juga menyiapkan kegiatan pendahuluan, kegiatan inti dan kegiatan penutup atau refleksi menyiapkan materi , menyiapkan lembar observasi kegiatan siswa dan guru selama KBM, dan membuat soal uraian untuk menguji hasil belajar siswa dengan menggunakan Metode Team Teaching.

Materi yang dibahas pada siklus II Sejarah Tradisi dan Masuknya Islam di Indonesia. Berdasarkan hasil observasi di setiap pertemuan pada siklus II ini antusias dan kreatifitas belajar siswa melaui Metode Team Teachinghampir aktif semua. Walaupun masih ada siswa yang kurang aktif dalam proses pembelajaran .

Pada siklus II ini, siswa sudah mulai terbiasa menggunakan Metode Team Teaching. Siswa yang sebelumya pasif atau kurang kreatif dan cenderung diam, dengan menggunakan Metode Team Teaching terbukti dapat meningkatkan hasil belajar siswa. Peneliti sudah berusaha untuk memaksimalkan dalam penerapan Metode Team Teaching, dan mendapat respon yang positif dan antusias dari siswa. Hasil belajar siswa meningkat 
dari siklus I dan II dibandingkan dengan proses pembelajaran yang tidak menggunakan Metode Team Teaching. Sehingga hipotesis tindakan dalam penelitian ini dapat terjawab bahwa diterapkan Metode Team Teachingdapat meningkatkanhasil belajar siswa.

b) Analisis hasil belajar

Tes yang dilakukan pada siklus II ini mencakup materi perkembangan Islam pada masa modern, sebanyak 10 soal essay. Secara keseluruhan pembelajaran pada tindakan siklus II ini cukup baik.

Dari penjelasan diatas dapat dilihat bahwa persentase ketuntasan belajar siswa kelas IX A SMP Taman Siswa Teluk Betung di siklus II, peneliti dapat menganalisis bahwa hasil belajar siswa meningkat dengan baik jika dibandingkan dengan sikulus I. Hasil belajar siswa telah bisa dikatakan tuntas karena telah mencapai ketuntasan belajar dengan KKM 80. Siswa yang tuntas belajar 31 orang siswa dari 35 siswa dengan ketuntasan belajar sebanyak $88 \%$ dengan nilai rata-rata siswa 85 .

\section{KESIMPULAN}

Berdasarkan pembahasan yang telah diuraikan, bahwa dari pertemuan setiap siklus ada peningkatan hasil belajar yang signifikan yang dialami oleh siswa kelas IX A SMP Taman Siswa Teluk Betung Bandar Lampung. Di siklus I adanya peningkatan dari sebelumnya pra siklus sebesar $22 \%$ saja yang tuntas menjadi $51 \%$ siswa yang tuntas. Siklus II terjadi peningkatan lagi dari yang sebelumnya di siklus I sebanyak 51\% menjadi $88 \%$ siswa yang tuntas dari KKM yang ditetapkan. Peneliti mengambil kesimpulan berdasarkan data hasil penelitian diatas bahwa dengan metode Team Teaching ini dapat meningkatkan hasil belajar siswa kelas IX A SMP Taman Siswa Teluk Betung Bandar Lampung.

\section{DAFTAR PUSTAKA}

Ahmadi dan Prasetya. Strategi Belajar Mengajar. Bandung: CV Pustaka Setia,2005.

Djam'an Satori \& Aan Komariah. Metode Penelitian Kualitatif. Bandung: Alfabeta. 2013. E. Mulyasa. Praktik Penelitian Tindakan Kelas. Bandung: PT Remaja Rosdakarya, 2009. Engkoswara. Dasar-Dasar Metodologi Pengajaran. Jakarta : PT Bina Aksara, 2003.

Hasan, M. Iqbal. Pokok-Pokok Materi Statistik 1, Jakarta: Bumi Aksara, 2003.

Jamal Ma'mur Asmani, Pengenalan Dan Pelaksanaan Lengkap MicroTeaching \&Team Teaching. Yogyakarta : Diva Press. 2010.

Kunand ar. Penelitian Tindakan Kelas. Jakarta : Rajawali Press. 2008. 
Muhibbin Syah. Psikologi Pendidikan Suatu Pendekatan Praktek Baru, Bandung : Rosdakarya, 1995.

Mulyono, Strategi Pembelajaran Menuju Efektivitas Pembelajaran Di Abad Global. Yogyakarta : UIN-Maliki Press. 2011.

Nana Sudjana. Cara Belajar Siswa Aktif Dalam Proses Belajar Mengajar, Bandung: Sinar Baru, 1989.

Penilaian Hasil Proses Belajar Mengajar Bandung: Remaja Rosdakarya, 2011.

Oemar Hamalik. Metode Belajar Dan Kesulitan-Kesulitan Belajar. Bandung : Tarsito. 2005.

Proses Belajar Mengajar Jakarta: Bumi Aksara, 2013.

Saifuddin Azwar. Metode Penelitian Pustaka, Yogyakarta: Pustaka Pelajar, 2010.

Slameto, Belajar dan Faktor-Faktor yang mempengaruhinya, Jakarta : PT Rineka Cipta, 1995.

Suharisimi Arikunto. Prosedur Penelitian Suatu Pendekatan Praktik, Jakarta: Rineka Cipta, 2013.

Syaiful Bahri Djamara. Strategi Belajar Mengajar. Jakarta : Rineka Cipta. 2010.

Wardani, IGAK. Team Teaching. Jakarta: Departemen Pendidikan Nasional. 2001. 